\title{
The Employability Skills of Higher Education Graduates: A Review of Literature
}

\author{
Ahmad Alzabadani Alrifai ${ }^{1}$, Valliappan Raju ${ }^{2}$ \\ Post Graduate Center, Limkokwing University of Creative Technology, Malaysia ${ }^{1,2}$
}

\begin{abstract}
Employability skills are identified as one of the valuable policy tools to upgrade mobility and earnings. Organization's employees are required to possess the knowledge and skills for increasing the organization's performance and competitiveness. Employability of graduates has become an issue that is not easy to be ignored in the global economy. However, the key employability skills need to be identify and categorised according to specific industry like interior design. It is a necessity to have a right set of employability skills for employer satisfaction. The purpose of this paper is to find out the required skill set for enhancing the employability of graduates and employees majorly focusing on interior design sector. This paper proposed the set of skills important for employability of interior design. Prominent databases were searched using combination of keywords and based on that 105 papers were selected for study. They were further filtered based on their title, abstract and findings and finally 25 papers were left. We have majorly focused upon eight sets of skills: communication skills, problem solving skills, teamwork skills, design skills, project management skills, computer skills, personal attributes and pre-graduates work experiences. On the basis of above-mentioned skills a checklist has been proposed which has been verified based on the literature review. The implications of this study will be helpful in guiding both industry and academia in incorporating and enhancing these skills among professionals
\end{abstract}

Keywords: Communication skills, problem solving skills, teamwork skills, design skills, project management skills, computer skills, personal attributes and pre-graduates work experiences

\section{INTRODUCTION}

In the context of education employability understand as employment rate gaining job during 6 months after graduate form higher education (Dacre Pool \& Sewell 2007). According (Lees 2002) the UK government used the employability rate as evaluation tools to measure the higher education performance Historically review presented in above, provide an overview of some of the main approaches to concept, and moreover, bring into light a variety of theoretical issues concerning employability. Employability can be used in various contexts but in operation context, it may not be that clear or precise (Hillage and Tamkin, 1999).

Table 1: Definitions of the Employability

\begin{tabular}{|l|l|}
\hline Reference & Definitions of the Employability \\
\hline $\begin{array}{l}\text { Hillage \& Pollard } \\
(1998)\end{array}$ & $\begin{array}{l}\text { "Employability is the capability to move self-sufficiently within the labour } \\
\text { market to realize potential through sustainable employment." } \\
\text { "The probability, for a given group, at a given time, of finding a job or } \\
\text { emerging from unemployment." }\end{array}$ \\
\hline Lefresne (1999) & "Employability is the ability of the graduate to get a satisfying job." \\
\hline Harvey 2001 & $\begin{array}{l}\text { "The continuously fulfilling, acquiring or creating of work through the optimal } \\
\text { use of competencies." }\end{array}$ \\
\hline $\begin{array}{l}\text { Heijaden(2005) } \\
\text { Marklon sverke \& } \& \text { (2006) }\end{array}$ & $\begin{array}{l}\text { "human capital indicated by education, competence development and job } \\
\text { tenure, has a positive relationship with perceived employability." }\end{array}$ \\
\hline Berntson (2008) & $\begin{array}{l}\text { "Employability refers to an individual's perception of his or her possibilities of } \\
\text { getting new, equal, or better employment." }\end{array}$ \\
\hline
\end{tabular}

According to some researchers, employability may be defined or described as the qualities, skills, competence and the ability to get a job and stay employed. (Berntsson, 2012; Knight \& Yorke, 2006; Van Der Heijde\& Van der Heijden, 2006; Hillage\& Pollard, 1999; De Grid, Van Loo and Sandlers, 1999). But at the same time,few other come up with the 


\section{International Advanced Research Journal in Science, Engineering and Technology}

Vol. 6, Issue 3, March 2019

argument that employability is just not about getting and acquiring abilities and qualities to get a job but it is related to the development and learning these abilities and qualities for the whole working life. (Harvey 2003; Bhaerman\& Spill, 1988). Various researchers have strived hard to know and understand what qualities, skills and abilities are needed to make a person employable. Many researchers found out that an emplyer should be mixture of experience, education and personal traits which impact individual emplyability. (Knights \& Yorke 2006; Hillage and Tamkin 1999; Van Der Heijde\& Van Der Heijden 2005; Harvey 2003). The perspectives and viewpoints of various researchers have been explained below to show the different views on employability.

\section{LITERATURE REVIEW}

Definitions of employability skills: Over the decades, the employability skills have been interesting countries like Canada, united states, New Zealand, Denmark, UK, Australia, and others...(Sung et al. 2013) and Malaysia, to define employability skills as part of their supporting to microeconomic target. Employability skills are known by a number of different terminologies of concept in different countries, such as 'core competencies', 'transferable skills', 'personal skills', key competencies', 'soft skills', describe the skills demanding in workplace(Naanda 2010). in the table 2.2 list of different concepts getting used for employability skills in different countries oversees.

Table 2 Different concept and terms of employability skills

\begin{tabular}{|l|l|}
\hline Country & Framework \\
\hline Canada & Employability skills \\
\hline France & Transferable skills \\
\hline Germany & Key qualifications \\
\hline Switzerland & Trans-disciplinary goals \\
\hline Denmark & Process independent qualifications \\
\hline United Kingdom & Key skills, common skills, core skills \\
\hline USA & Workplace know-how, necessary skills, Basic skills \\
\hline Australia & Key competencies, employability skills, generic skills \\
\hline Singapore & Critical enabling skills training \\
\hline Malaysia & employability skills \\
\hline
\end{tabular}

According to (Sung et al. 2013; Matters \& Curtis 2008; Kämäräinen 2002) there are lack of common agreement language and understanding concept to employability skills can use in different forums in contexts. Find common terminology for employability, it is desirable between stakeholders for example higher education, individuals, employers and communities, as Kearns 2001 added (Naanda 2010).

A number of researchers have established several employability models from a wide range of conceptual and disciplinary perspectives, for example (Hillage and Pollard 1998, \& Harvey, 2004). Perhaps, one of the most comprehensive models is provided by McQuaid and Lindsay (2005) (M\&L) because, before proposing the model, they analysed different conceptual and disciplinary perspectives of employability from previous literature. Alternatively, one may simply consider the M\&L (2005) model of employability because of the prominence is given to the employability skills necessary for employability.

\section{a. The employability skills in Review of the literature in Malaysia}

In this section the research review previous studies done in Malaysian context to identify the employability skills from employers' view about preparation of graduates as direct way to identify employability. In Malaysian context skills workplace have been studied widespread attention in their scholars and commonly debated in in different fields and various places. Architect (Salleh et al. 2016), Engineering and information and communication technology (computer) (Saad \& Majid 2014), real estate (Adnan et al. 2012), Manufacture industry (Rasul, Abd Rauf, et al. 2012), General (Islam et al. 2013), open university Malaysia(Latif 2014), Accounting (Shamsuddin et al. 2015). Attributes of graduate's architects; an industry perspective (Salleh et al. 2016), they were studied view of employers according importance of graduate's attributes of architects in Malaysia. The study done used quantitively method by distributed 250 questionnaires for Malaysians Architecture to collection data, 65 finalized were returned. The items of questionnaire identified by reviewed and screening process employability skills in different pervious literature review after that the experts finalized final list of attributes by determined 10 attributes such as teamwork, leadership, creativity, positives attitudes, responsibility, interpersonal and independence. 5-point Likert used to determine the important skills and rate attributes. The finding that the teamwork, positive attitude and responsibility were ranked the 


\section{International Advanced Research Journal in Science, Engineering and Technology}

Vol. 6, Issue 3, March 2019

highly important by $4.62,4.65$ and 4.73 respectively. The study contributed by providing the industry perspective according to employability skills wanted. Education provides productivity enhancing skills that employers value and reward (Bol, 2015) and through education, individuals can increase their relative position among other suppliers of labor. Moreover, although employability has been broadly defined as a collection of skills, attributes, and characteristics that employers expect from workers (Lowden et al., 2011), there is a lack of research to indicate how employability may be uniquely defined for graduate students. As detailed later, the skills, attributes and characteristics developed by graduate level students differ than those developed at the undergraduate level, yet the limited empirical studies on employability remain focused on employability of individuals who recently completed undergraduate level education (Finch et al., 2013; Wickramasinghe and Perera, 2010). Additionally, while researchers (e.g. Wickramasinghe and Perera, 2010) identify a need to empirically evaluate and define employability, our understanding of employability remains largely theoretical. Furthermore, even though employers are important decision makers in labor market outcomes, the limited empirical studies on employability focus largely on employee or student perceptions of employability (e.g. Blackwell et al., 2001; Gault et al., 2000).

Table 3: Employability skills according to various reference from review of literature

\begin{tabular}{|c|c|c|c|c|c|c|c|}
\hline & 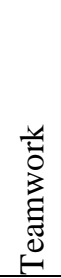 & $\begin{array}{l}\stackrel{0}{\Xi} \\
0 \\
0 \\
0 \\
0 \\
0 \\
0 \\
0 \\
0\end{array}$ & 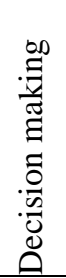 & 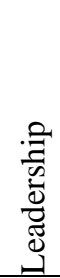 & 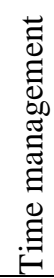 & 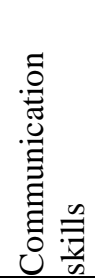 & 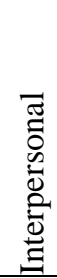 \\
\hline Salah et al (2015) & $\mathrm{x}$ & $\mathrm{x}$ & $\mathrm{x}$ & $\mathrm{x}$ & $\mathrm{x}$ & & \\
\hline Anon (2016) & & & & & $\mathrm{x}$ & $\mathrm{x}$ & $\mathrm{x}$ \\
\hline Asmaak \& Corresponding (2010) & $\mathrm{x}$ & $\mathrm{x}$ & & & & & $\mathrm{x}$ \\
\hline Shamsuddin et al. (2015) & & & & & & $\mathrm{x}$ & \\
\hline Islam et al. (2013) & & & & & & $\mathrm{x}$ & $\mathrm{x}$ \\
\hline Adnan et al. (2012) & $\mathrm{X}$ & $\mathrm{X}$ & & & & & \\
\hline Rasul, Abd Rauf, et al. (2012) & & & & & & & $\mathrm{x}$ \\
\hline (Sermsuk et al. 2014) & & $\mathrm{x}$ & & & & $\mathrm{x}$ & \\
\hline
\end{tabular}

\section{RESEARCH METHODOLOGY}

It is the systematic and methodical process of searching, filtering, and classifying research papers. After reviewing 105 research papers which were selected via an automated search in seven prominent databases ProQuest, Elsevier, Emerald, Springer, Deloitte, TechSci Research, LSI Financial Services and Google Scholar. To identify the relevant research papers from these databases subsequent combination of keywords are used like "Employability skills," "Interior design Industry," "Employability Skills," "Employment," "Training Need Analysis," and "Training". The papers considered for this research were published on or before December 2016. The preliminary search resulted into a total of 105 hits, and then afterwards these research papers were filtered in two steps. In initial step of filtrationinvolves the manual scanning of the titles of all the research papers so as to remove the irrelevant ones. This resulted in the segregation of research papers, elimination of duplicates and opinion articles. The next step of the filtration involved reading the abstract and complete text of the research papers, if requisite. By applying this process of filtration, we were able to removed papers that didn't talk about employability skills and Interior design Industry as the pivotal concept, but simply cited them in the text. After this step, we were remained with only 25 peer- reviewed papers which are closely related with the concepts of the employability skills needed in Interior design Industry. This result reflected the need of identifying the skills required in Interior design Industry. The reviewed research paper assists us to identify the nine employability skills needed in the Interior design Industry.

\section{FINDINGS AND DISCUSSION}

Out of 25 research papers reviewed following skills were identified needed for employees in Design. Table 1, represents the nine skills viz. Communication skills, computer skills, Work Psychology skills, Teamwork skills, Interpersonal skills, Critical Thinking and Problem Solving skills, Self-management skills, Planning and Organizing skills and Conceptual and Analytical skills were identified, which are the backbone of any successful organization. Table 4 provides a list of employability skills used by each study discussed above. A comparison was made on the 


\section{International Advanced Research Journal in Science, Engineering and Technology}

Vol. 6, Issue 3, March 2019

employability skills perceived to be important to graduates. The importance of the various skills of each study concerned was ranked based on the frequency of their appearances in these studies. It is assumed skills that were highly ranked were important skill. Table 5 shows the ranking of employability skills in respect to the studies concerned. There were only three employability skills (ranked first and second) that were significantly important, and these are as follow:

Table 4: Employability Skills

\begin{tabular}{|c|c|c|c|c|c|c|}
\hline $\begin{array}{l}\text { (Saunders } \\
\text { and Zuzel, } \\
2010)\end{array}$ & $\begin{array}{l}\text { (Yuzainee, } \\
\text { Zaharim and } \\
\text { Omar, 2011) }\end{array}$ & $\begin{array}{l}\text { (Islam, Abdul } \\
\text { Hamid and } \\
\text { Manaf, 2013) }\end{array}$ & $\begin{array}{c}\text { (Mohd } \\
\text { Shamsuri and } \\
\text { Izaidin, 2014) }\end{array}$ & $\begin{array}{c}\text { (Shamsuddin, } \\
2015)\end{array}$ & $\begin{array}{c}\text { (Munohsamy, } \\
\text { 2015) }\end{array}$ & $\begin{array}{l}\text { (Salah et } \\
\text { al ,2015) }\end{array}$ \\
\hline $\begin{array}{c}\text { Oral } \\
\text { Communicati } \\
\text { on } \\
\text { Enthusiasm } \\
\text { Understandin } \\
\text { g Concepts } \\
\text { Integrity } \\
\text { Commitment } \\
\text { Cooperation } \\
\text { Team- } \\
\text { Working } \\
\text { Dependability } \\
\text { Questioning/ } \\
\text { Listening } \\
\text { Attention to } \\
\text { Details }\end{array}$ & $\begin{array}{c}\text { Communicatio } \\
\text { n Skills } \\
\text { Decision- } \\
\text { Making skills } \\
\text { Problem } \\
\text { Solving Skills } \\
\text { Professionalis } \\
\text { m } \\
\text { Team working } \\
\text { skills }\end{array}$ & $\begin{array}{l}\text { computationa } \\
\text { l skills } \\
\text { management } \\
\text { skills } \\
\text { interpersonal } \\
\text { skills } \\
\text { critical } \\
\text { thinking } \\
\text { skills } \\
\text { enterprise } \\
\text { skills } \\
\text { communicati } \\
\text { on skills }\end{array}$ & $\begin{array}{c}\text { Problem } \\
\text { Solving Skills } \\
\text { Communicati } \\
\text { on Skills } \\
\text { Presentation } \\
\text { Skills } \\
\text { Team } \\
\text { working } \\
\text { Tool } \\
\text { Handling } \\
\text { Competency }\end{array}$ & $\begin{array}{c}\text { functional } \\
\text { skills } \\
\text { communicati } \\
\text { on skills } \\
\text { Organizationa } \\
1 \& \\
\text { management } \\
\text { skills }\end{array}$ & $\begin{array}{c}\text { Interpersonal } \\
\text { Skills } \\
\text { Team Working } \\
\text { Solving } \\
\text { Problem skills } \\
\text { Communicatio } \\
\text { n Skills. } \\
\text { Leadership } \\
\text { Decision- } \\
\text { Making } \\
\text { Lifelong } \\
\text { Learning } \\
\text { Skills } \\
\text { computer } \\
\text { Skills }\end{array}$ & $\begin{array}{c}\text { Problem } \\
\text { Solving } \\
\text { Decision } \\
\text { Making } \\
\text { Time } \\
\text { Manage } \\
\text { ment } \\
\text { Commun } \\
\text { ication } \\
\text { Skills } \\
\text { Interpers } \\
\text { onal }\end{array}$ \\
\hline
\end{tabular}

Table 5: The Ranks of Employability Skills Based on Previous studies.

\begin{tabular}{|c|c|c|c|}
\hline Rank (No. Of & Employability & Rank (No. Of & Employability \\
\hline Studies) & Skills & Studies) & Skills \\
\hline I (6 OUT OF 7) & \multirow{2}{*}{$\begin{array}{l}\text { Communication } \\
\text { Teamwork }\end{array}$} & 4 (1 Out Of 7) & Questioning/Listeni \\
\hline I (6 OUT OF 7) & & 4 (I Out Of 7) & Attention to Detail \\
\hline 2 (5 OUT OF 7) & Problem Solvina & 4 (I Out Of 7) & $\begin{array}{c}\text { Enthusiasm/Willing } \\
\text { To Team }\end{array}$ \\
\hline 3 (2 OUT OF 7) & \multirow{2}{*}{$\begin{array}{l}\text { Leadership Skills } \\
\text { Skills }\end{array}$} & 4 (I Out Of 7) & Intearitv \\
\hline 3 (2 OUT OF 7) & & 4 (I Out Of 7) & Commitment \\
\hline 3 (2 OUT OF 7) & Self- & 4 (I Out Of 7) & Understanding \\
\hline 3 (2 OUT OF 7) & Decision Making & 4 (I Out Of 7) & Self-Confidence \\
\hline \multirow[t]{2}{*}{3 (2 OUT OF 7) } & \multirow[t]{2}{*}{ Interpersonal } & 4 (I Out Of 7) & Positive Attitude \\
\hline & & & IVOrk \\
\hline 3 (2 OUT OF 7) & \multirow{2}{*}{$\begin{array}{l}\text { Business Skills } \\
\text { Planning }\end{array}$} & 4 (I Out Of 7) & Leanina Skills \\
\hline 4 (I OUT OF 7) & & 4 (I Out Of 7) & Professionalism \\
\hline \multirow[t]{2}{*}{4 (I OUT OF 7) } & \multirow[t]{2}{*}{ Critical Analvsis } & 4 (I Out Of 7) & Literacy and \\
\hline & & & Relevant to The \\
\hline 4 (I OUT OF 7) & Time & 4 (I Out Of 7) & Initiative \\
\hline 4 (1 OUT OF 7 ) & $\begin{array}{c}\text { Skills } \\
\text { ENGLISH }\end{array}$ & & \\
\hline
\end{tabular}

\section{CONCLUSION AND LIMITATIONS}

Organizations need people with high employability skills. It becomes important to acquire best of talent, in order to survive in cut-throat competition. However there is dearth of studies in Interior design Sector on employability skills in Malaysia. Employability Skills are just not those minimum skills needed to perform a job, rather this is the backbone for any service providing organization. Since Interior design, deals directly with the design it is mandatory to assure 


\title{
International Advanced Research Journal in Science, Engineering and Technology
}

\author{
Vol. 6, Issue 3, March 2019
}

right kind of skills are trained time to time. For training employees, it becomes essential to segregate the kind of skill required at various job profiles. This paper is an attempt to provide necessary employability skills needed in interior design from the previous studies. Most of the literature has not touched few skills like computer skills, design skills and pre-graduates work experience, but the escalating demand of technology based infrastructure has increased the use of computer at workplace. Most of the research work is confined outside Malaysia. For an industry which is booming so fast and employee's higher number of people, it becomes important to select, train or retain them as per the skill meter

\section{REFERENCES}

[1]. Agencia perala Qualitat del Sistema Universitari de Catalunya, 2015. Employers' perceptions of the employability and skills of recent graduates in Catalonia. , pp.1-108.

[2]. Agency, M.Q., 2017. Malaysain Qualifications Framework (MQF) version 2.0, Available at: http://www.mqa.gov.my/PortalMQAv3/dokumen/maklum balas/MQF V2 DRAFT3.pdf.

[3]. Aida, B., Norailis, a. W. \& Rozaini, R., 2015. Critical Success Factor of Graduate Employability Programs. Journal of Economics, Business and Management, 3(8), pp.767-771. Available at: http://www.joebm.com/index.php?m=content\&c=index\&a=show\&catid=46\&id=587.

[4]. Alnachef, T., 2018. The effect of intellectual capital components on competitive advantage and business performance in syrian pharmaceutical industry. Limkokwing university of creative technology.

[5]. Alves, H., and Raposo, M. (2007a). Conceptual model of student satisfaction in higher education. Total Quality Management, 18(5), 571-588.

[6]. Alves, H., and Raposo, M. (2007b). Student satisfaction index in Portuguese public higher education. The Service Industries Journal, 27(6), 795-808.

[7]. Anctil, Eric., (2008). Selling Higher Education: marketing and advertising America's Colleges and Universities: ASHE Higher Education Report, Vol. 34 (no. 2). Las Vegas: ASHE Higher Education Report Series.

[8]. Anderson, E., and Sullivan, V. (1993). The antecedents and consequences of customer satisfaction for firms. Marketing Science, $12,125-143$.

[9]. Belanger, C., Mount, J., and Wilson, M. (2010). Institutional image and retention. Tertiary Education and Management, 8(3), 217-230.

[10]. Brown, R., and Mazzarol, T. (2009). The importance of institutional image to student satisfaction and loyalty within Higher Education. Higher Education, 58, 81-95.

[11]. Butt, B., and Rehman, K. (2010). A study examining the students satisfaction in Higher Education. Procedia Social and Behavioral Sciences, 2, 5446-5450.

[12]. Campostrini, S., and Gerzeli, S. (2007). Informative sources for the evaluation of the university education effectiveness in Italy. In L. Fabbris (Ed.), Effectiveness of university education in Italy. Employability, competences, human capital (pp. 2-9). Padua: Physica-Verlag.

[13]. Cassel, C., and Eklof, J. A. (2001). Modelling customer satisfaction and loyalty on aggregate levels: Experience from the ECSI pilot study. Total Quality Management, 12(7and8), 834-841. Catramby, T. C., and Costa, S. R. (2004).

[14]. Chiandotto, B., Bini, M., and Bertaccini, B. (2007). Quality assessment of the university educational process: An application of the ECSI model. In L. Fabbris. (Ed.), Effectiveness of university education in Italy. Employability, competences, human capital (pp. 43-54). Padua: Physica-Verlag.

[15]. Chin, W., and Newsted, P. (1999). Structural equation modeling analysis with small samples using partial least squares. In R. Hoyle (Ed.), Statistical strategies for small sample research (pp. 307-342). Thousand Oaks, CA: Sage.

[16]. Chin, W. (1998). The partial least squares approach to structural equation modeling. In G. A. Marcoulides (Ed.), Modern methods for business research (pp. 295-336). London: Lawrence Erlbaum Associates.

[17]. Chitty, B. and Soutar, G. (2004). Is the European Customer Satisfaction Index Model Applicable to Tertiary Education? ANZMAC 2004 Conference Wellington (pp. 1-7). Australian and New Zealand Marketing Academy.

[18]. De Vos, A., De Hauw, S., and Van der Heijden, B. (2011). Competency development and career success: The mediating role of employability. Journal of Vocational Behavior, 79, 438-447.

[19]. Dillon, W., and Goldstein, M. (1984). Multivariate analysis. Methods and applications. New York: Wiley. Engberg, M.E (2007). Educating the workforce for the 21 st century: a cross-disciplinary analysis of the impact of the undergraduate experience on students' development of a pluralistic orientation. Research in Higher Education, 3(48), 283-317.

[20]. Eskildsen, J., Martensen, A., Gronholdt, L., and Kristensen, K. (2000). Benchmarking student satisfaction in higher education based on the ECSI methodology. sinergie raporti di ricerca, 9, 385-402.

[21]. Fornell, C., and Larcker, D. (1981). Structural equation models with unobservable variables and measurement error: Algebra and statistics. Journal of Marketing Research, 18(3), 328-388.

[22]. Gedye, S., Fender, E., and Chalkley, B. (2004).Students' undergraduate expectations and post-graduation experiences of the value of a degree. Journal of Geography in Higher Education, 28(3), 381-396.

[23]. Gefen, D., and Straub, D. (2005). A practical guide to factorial validity using PLS-graph: Tutorial and annotated example. Communications of the Association for Information Systems, 16(25), 91-109.

[24]. González, M., Comesaña, L., and Brea, J. (2007). Assessing tourist behavioral intentions through perceived service quality and customer satisfaction. Journal of Business Research, 60, 153-160.

[25]. Hair, J., Ringle, C., and Sarstedt, M. (2011). PLS-SEM: Indeed a silver bullet. Journal or Marketing Theory and Practice, 19(2), $139-151$.

[26]. Hartman, D., and Schmidt, S. (1995). Understanding student/alumni satisfaction from a consumer's perspective. Research in Higher Education, 36(2), 197-217.

[27]. Harvey, L. (2001). Defining and measuring employability. Quality in Higher Education, 7(2), 97-109.

[28]. Harvey, L. (2010). New realities: The relationship between higher education and employment. Tertiary Education and Management, 6(1), 3-17.

[29]. Hemsley-Brown, J. (2012). 'The best education in the world': Reality, repetition or cliché? International students' reasons for choosing an English University. Studies in Higher Education, 37(8), 1005-1022.

[30]. Hennig-Thurau, T., Langer, M., and Hansen, U. (2001). Modeling and managing student loyalty: An approach based on relationship quality. Journal of Service Research, 4, 331-344.

[31]. Hillage, J., and Pollard, E. (1998). Employability: Developing a framework for policy analysis. EfEE Research Briefing, 85, 85.

[32]. Johnson, M., Gustafsson, A., Andreassen, T. W., Lervik, L., and Cha, J. (2001). The evolution and future of national customer satisfaction index models. Journal of Economic Psychology, 22, 217-245.

[33]. Kivinen, O., and Nurmi, J. (2007). Job requirements and competences: do qualifications matter? In U. Techler (Ed.), Careers of university graduates (pp. 131-142). Kassel: Springer.

[34]. Knight, P., and Yorke, M. (2003). Employability and good learning in higher education. Teaching in Higher Education, 8(1), 3-16. 


\section{International Advanced Research Journal in Science, Engineering and Technology}

Vol. 6, Issue 3, March 2019

[35]. Kohler, J. (2004). The bologna process and employability: The impact of employability on curricular development. A key objective of academic studies and for academic institutions. Conference Bled/Slovenia (p. 1-21). Bled/Slovenia: s.e.

[36]. Kristensen, K., Kanji, G., and Dahlgaard, J. (1992). On measurement of customer satisfaction. Total Quality Management, 3(2), $123-128$.

[37]. Kristensen, K., Martensen, A., and Gronholdt, L. (2000). Customer satisfaction measurement at post Denmark: Results of application of the european customer satisfaction index methodology. Total Quality Management, 11(7), 1007-1015.

[38]. Kristensen, K., Martensen, A., and Gronholdt, L. (1999). Measuring the impact of buying behaviour on customer satisfaction. Total Quality Management 10(4/5), 602-614.

[39]. Kurtz, D., Clow, K., Ozment, J., and Ong, B. (1997). The antecedents of consumer expectations of services: An empirical study across four industries. The Journal of Services Marketing, 11(4), 230-248.

[40]. Martensen, A., Grønholdt, L., Eskildsen, J., and Kristensen, K. (2000). Measuring student oriented quality in higher education: Application of the ECSI methodology. Sinergie Rapporti di Ricerca, 9, 371-383.

[41]. Mason, G., Williams, G., and Cranmer, S. (2009). Employability skills initiatives in higher education: What effects do they have on graduate labour market outcomes?. Education Economics, 17(1), 1-30.

[42]. Vinzi, V., Chin, W., Henseler, J., and Wang, H. (2010). Handbook of partial least squares. Concepts, methods and applications.

[43]. Heidelberg: Springer. Vrontis, D., Thrassou, A., and Melanthiou, Y. (2007). A contemporary higher education student-choice model for developed countries. Journal of Business Research, 60, 979-989.

[44]. Webb, D., and Jagun, A. (1997). Customer care, customer satisfaction, value, loyalty and complaining behavior: validation in a UK university setting. Journal of Consumer Satisfaction, Dissatisfaction and Complaining Behavior, 10, 139-151.

[45]. Yorke, M. (2004). Employability in the undergraduate curriculum: some student perspectives. European Journal of Education, 39(4), $109-427$. Zeithaml, V. (1987). Defining and relating price, perceived quality and perceived value (Report no. 87-101). Cambridge: Marketing Science Institute. 